\title{
The Odd-Even Effect in The Boards of Commissioners and Corporate Values
}

\author{
Ardhi Islamudin ${ }^{1}$, Gerrinko Giffari Wurintara ${ }^{2 *}$, Yustrida Bernawati ${ }^{3}$
}

AFFILIATION:

1,2,3 Faculty of Economics and Business, Universitas Airlangga, Indonesia

\section{*CORRESPONDENCE:}

gifarigerinko@gmail.com

THIS ARTICLE IS AVAILABLE IN:

https://ojs.unud.ac.id/index.php/jiab

DOI:

10.24843/JIAB.2020.v15.i02.p12

\section{CITATION:}

Islamudin, A., Wurintara, G. G., \& Bernawati, Y. (2020). The Odd-Even Effect in The Boards of Commissioners and Corporate Values. Jurnal IImiah Akuntansi dan Bisnis, 15(2), 308-316.

\section{ARTICLE HISTORY}

Received:

08 January 2020

\section{Revised:}

04 June 2020

\section{Accepted:}

06 July 2020

\begin{abstract}
This article enlarges the literacy about the characteristics on board of commissioners by adding a new perspective, namely the odd-even effect in board of commissioners' structure. This type of research was quantitative research. When the board of commissioners is formed with an odd number, the decision making process will be easier and more efficient. It is because there is no possibility of a voting tie and result the one directional perspective. It is different, when the board of commissioners is formed with an even number. It will trigger a voting tie in the decision making process. Therefore, there is a possibility of different perspective in the board of commissioners. As a result, the odd or even proportions number in the board of commissioners affects the corporate value. The smaller number board of commissioner's forms a stronger board of commissioners. Then, the company that have odd boards of commissioners has a higher corporate value than the company that has an even board of commissioners.
\end{abstract}

Keywords: Corporate value, odd-even effects, board of commissioners.

\section{Introduction}

Jensen \& Meckling (1976) explain about the agency relationship that arises when the principal involves another person (agent) to provide services or delegate authority in making a decision for the agent. The contract between the agent and the principal causes an agency problem, because each party seeks to maximize their own utility. Eisenhardt (1989) explain the contract between the principal and agent causes two main problems namely moral hazard and adverse selection. The Moral hazard refers to the condition that the agent's activities are not fully known by the principal. There are possibilities that the agent takes a policy not in accordance with the company interests. Adverse selection refers to the condition that the agent has better knowledge than the principal. There are possibilities that some of the information is not conveyed and it affects the decision-making process. Therefore, the control mechanisms are needed to control agent actions.

One of the mechanisms that can reduce and overcome agency problems is corporate governance. Cadbury (1992) defines corporate 


\section{Islamudin, Wuriantara \& Bernawati \\ The Odd-Even Effect in The Boards of Commissioners and Corporate Values}

governance as a system that directs and controls the company path walk. In a good corporate governance system, it allows the board of directors to develop the company, but using that freedom within an effective accountability framework. Agency theory is the driving the emergence of the concepts Good Corporate Governance (GCG) in Business Company. Through supervision in the GCG mechanism, it is expected to minimize negative actions of the agent. The GCG mechanism is a guarantee to shareholders that the investment funds have been managed well and the agent has worked in line with their functions, responsibilities and giving benefit to the company (Hamdani, 2016). GCG mechanism also has positive relations with corporate value (Damayanthi, 2019).

In general, there are two corporate governance systems implemented in the world, one tier board and two tier boards. Generally one tier board is adopted by AngloSaxon countries such as England and America, while two tier boards are adopted by Continental European countries such as the Netherlands and Germany (Rasyidah, 2013) . In the two tier boards, the corporate structure is separated into two groups namely supervisory boards and executive boards. Meanwhile, in one tier board, the supervisory and executive functions are combined in the same board (Tricker \& Tricker, 2015). Indonesia is one of the countries that uses the two tier board governance system, the board of commissioners carries out the supervisory function while the executive function is carried out by the board of directors.

As part of the supervisory or executive function, the board of commissioners and the board of directors will determine the success of the company. The characteristics of the board are a part in influencing the successes of the company. Therefore, understanding the relationship between the characteristics of the board and the efficiency of the board of commissioners performance or directors is an interesting research issue that has attracted various (Deng et al., 2012; Gao \& Huang, 2018). Several literacy studies in the finance field have explored various aspects of the board's characteristics toward their performance or corporate value, such as female directors (Campbell \& Vera, 2010; Darmadi, 2013; Ullah et al., 2019), foreign director (Masulis et al., 2012; Oxelheim \& Randøy, 2003). and independent commissioners (Muryati \& Suardikha, 2014; Prabowo \& Simpson, 2011). The board characteristics play an important role in taking decisions by the board's personal. It can be reflected in the performance and corporate value. According to Harmono \& Si (2009) the corporate value is the company's performance which is reflected by the stock price formed by the demand and supply of the capital market that reflects the public's assessment of the company's performance. High firm value is the desire of the owners of the company, because with high firm value shows the prosperity of shareholders is also high (Hemastuti \& Hermanto, 2014). The objective of corporate management is to maximize shareholder wealth (Schellenger et al., 1989). Indeed, this article extends the literacy of the board by adding a new perspective that is odd-even effect in the board structure.

This article is motivated from Gao \& Huang (2018) and He \& Luo (2018) research. Gao \& Huang (2018) indicates that an audit by even number committee is more likely to restate financial statements. He \& Luo (2018) revealed that even corporate boards in developed country markets have more agency problems. Motivated from this case, this article test the odd even affect method on the supervisory board. As we know, this article is the first article that links the odd even affect in the structure of the board of commissioners with the corporate value. Previous article, Gao \& Huang (2018) links the 


\section{Islamudin, Wuriantara \& Bernawati \\ The Odd-Even Effect in The Boards of Commissioners and Corporate Values}

odd even effect to the audit committee structure, whereas He \& Luo (2018) links the odd even affect to the board of directors' structure.

Board structures with an even number have weaker monitoring and more easily involved in agency problems. The even number boards is considered inefficient in decision-making. The board will usually make decisions through voting. Based on the assumption of a voting tie, a board with an even number will have a tendency facing a voting tie. It is different with the council with an odd number which does not facing a voting tie, so that the council tends to be inefficient in making a decision and monitoring because of conflicts resulting from voting ties (He \& Luo, 2018)

Furthermore, He \& Luo (2018) argues that even the number of boards with fewer board meetings and more director absences from board meetings. That case implies that even the number of boards have less intention to work hard in monitoring the executive. He \& Luo (2018) mentions that the board of directors with an even number is positively related to various agency problems, including inter-company loans, loan guarantees for related parties, and too much excessive consumption. It was also found that companies that have an even number of boards are more likely to accept modified audit opinions and experience an accounting irregularity. Based on the theoretical and previous research results, the hypothesis in this study is as follows.

$\mathrm{Ha}$ : Odd-even board commissioners affect the value of the company.

\section{Research Method}

This research was conducted on companies listed in the LQ 45 Index from 2015 to 2018. LQ 45 companies were companies that were considered having a good corporate governance and corporate fundamentals. The criteria for determining the sample were companies that were consistently listed in the LQ 45 index during the study period. There are 45 companies listed on the LQ45 index in 2015, but only 32 companies consistently listed on the index during the study period so that during the 4 years study period 128 samples were obtained. The explanation is as follows:

The object of research was the corporate value and the odd-even board of commissioners. The dependent variable in this study was the corporate value $(\mathrm{Y})$, while the independent variable in this study was the odd-even board of commissioners (X). By considering the many factors that might affect the corporate value, testing the influence of the odd-even board of commissioners on the corporate value used several control variables. This method used to protect the influence of independent variables toward the dependent variable was not projecting biased. The control variables that used were company size, leverage, independent commissioners, female commissioners, and board size.

Table 1 Research Sample Selection Process

\begin{tabular}{lr}
\hline Criteria & Total Company \\
\hline The research population is the company listed at LQ45 & 45 \\
Inconsistencies were noted in LQ45 during the study period & $(13)$ \\
Total sample companies & 32 \\
Observation period & 4 \\
Total research sample & 128 \\
\hline
\end{tabular}

Source: Processed Data, 2020 
The independent variable in this study was the corporate value which measured using Tobins' $Q$. The Tobins' $Q$ Ratio was an accurate and trusted measure of corporate value in determining potential management in managing resources and investment growth (Sudiyatno \& Puspitasari, 2010; Tambunan et al., 2017). The higher the score of this ratio meant the better the corporate value resulted. The Tobin's $Q$ ratio calculation formula refers to Chung \& Pruitt (1994).

Q = Corporate Value

$$
\mathrm{Q}=\frac{(\mathrm{MVS}+\mathrm{PS}+\mathrm{D})}{\mathrm{TA}}
$$

MVS = Market value of all outstanding shares

$\mathrm{D} \quad=$ Debt

TA $=$ Total Asset

The dependent variable in this research was measured using a dummy variable, the value of 1 was given to companies that have an odd number of commissioners, while the value of 0 would be given to companies that had an even number of commissioners. Company size was measured by the natural logarithm of the company's total assets. The calculation formula is as follows.

$$
\begin{array}{ll}
\text { Size } & =\text { Company Size } \\
\text { Ln } & =\text { Natural Logarithm }: \text { LN(TA) } \\
\text { TA } & =\text { Total asset } \\
& \text { Leverage measured using Debt to Asset Ratio (DAR), with the following calculation }
\end{array}
$$
formula:

DAR = Debt to Asset Ratio

$$
\text { DAR }=\frac{\text { Total Liability }}{\text { Total Asset }}
$$

Independent commissioners were measured using the percentage of independent commissioners on the board of commissioners. Female commissioners were measured using the percentage of female commissioners on the board of commissioners. While, the board size was measured using the number of the board of commissioners. Furthermore, this research used quantitative data types and using secondary data. The secondary data was a company annual reports, which are accessed through www.idx.co.id. The data in this study were collected by the nonparticipant observation method. Data analysis techniques in purpose to answer hypotheses in research used multiple linear regression analysis.

\section{Result and Discussion}

The dependent variable in this study is the Odd / Even commissioner or it can be said as a dummy variable. It can be seen from the Table 2 . that means the score of the variable is 0.507 . That data shows that this variable is fairly and evenly distributed. It is proved from mean score in descriptive statistics places in the middle. The size and leverage control variables have mean score 31,672 and 0.510 . The independent commissioner control variable, has a mean score 0.435 .

It means that the average independent board of commissioners within the board of commissioners' structure is $43.5 \%$. The female commissioner control variable has a mean score 0.075 . It means that only the percentage of female commissioners in the sample company is only $7.5 \%$. 
Islamudin, Wuriantara \& Bernawati

The Odd-Even Effect in The Boards of Commissioners and Corporate Values

Table 2. Statistics Analysis Descriptive Result

\begin{tabular}{llrrrr}
\hline & $\mathrm{N}$ & Minimum & Maximum & Mean & \multicolumn{2}{c}{$\begin{array}{l}\text { Deviation } \\
\text { Std. }\end{array}$} \\
\hline Odd Even Commissioner & 128 & 0.000 & 1.000 & 0.508 & 0.502 \\
Size & 128 & 28.989 & 34.799 & 31.672 & 1.387 \\
Leverage & 128 & 0.001 & 0.919 & 0.510 & 0.224 \\
Independent & 128 & 0.300 & 0.833 & 0.436 & 0.118 \\
Commissioner & & 0.000 & 0.333 & 0.075 & 0.107 \\
Female Commissioner & 128 & 3.000 & 13.000 & 6.336 & 2.074 \\
Board Size & 128 & 0.605 & 23.286 & 2.625 & 3.660 \\
Tobins Q & 128 & & & &
\end{tabular}

Source: Processed Data, 2020

The board size control variable has a minimum score of 3 and a maximum score of 13 , this is in accordance with UUPT article 108 paragraph 3 which states that the board of commissioners consists of one or more members.

Table 2. shows the results of descriptive statistical analysis using SPSS. Descriptive statistics provide a data description such as average score (mean), standard deviation, variance, maximum, minimum, sum, range, kurtosis, and skewness.

The hypothesis in this study was answered by using linear regression analysis by considering the significance or probability level of the dependent variable (odd-even commissioner) toward the independent variable (corporate value). If the probability score is $\geq 0.05$, then the alternative hypothesis $(\mathrm{Ha})$ is rejected and the hypothesis $(\mathrm{Ho})$ is accepted. Indeed, the results of the linear regression analysis are presented in Table 3.

Based on the results of the hypothesis that testing in Table 3. it can be seen that the statistical $F$ has a significance score 0,000 . That score proves that the built research model is based on the dependent variable (odd even commissioners) and control variables (size, leverage, independent commissioners, female commissioners, and board size) is a feasible model.

Table 3. Hypothesis Testing with Multiple Linear Regression

\begin{tabular}{|c|c|c|c|c|c|}
\hline & \multicolumn{2}{|c|}{$\begin{array}{l}\text { Unstandardized } \\
\text { Coefficients }\end{array}$} & \multirow{2}{*}{$\begin{array}{l}\text { Standardized } \\
\text { Coefficients } \\
\text { Beta }\end{array}$} & \multirow[t]{2}{*}{$\mathrm{t}$} & \multirow[t]{2}{*}{ Sig. } \\
\hline & $B$ & Std. Error & & & \\
\hline (Constant) & 54.817 & 6.800 & & 8.064 & 0.000 \\
\hline Odd-Even Commissioner & 1.082 & 0.510 & 0.148 & 2.121 & 0.036 \\
\hline Size & -2.001 & 0.240 & -0.759 & -8.307 & 0.000 \\
\hline Leverage & 3.913 & 1.370 & 0.239 & 2.858 & 0.005 \\
\hline Commissioner Independent & 14.540 & 2.320 & 0.466 & 6.266 & 0.000 \\
\hline Female Commissioner & 0.441 & 2.360 & 0.013 & 0.187 & 0.852 \\
\hline Board Size & 0.361 & 0.140 & 0.204 & 2.625 & 0.010 \\
\hline Adjusted R Square & & & & & 0.426 \\
\hline F Statistic & & & & & 16.730 \\
\hline F Significant & & & & & 0.000 \\
\hline
\end{tabular}

Source: Processed Data, 2019 
Islamudin, Wuriantara \& Bernawati

The Odd-Even Effect in The Boards of Commissioners and Corporate Values

Table 4. Mann-Whitney U Test Results

\begin{tabular}{lr}
\hline \multicolumn{2}{c}{ Tobins_Q } \\
\hline Mann-Whitney U & $1,585.000$ \\
Wilcoxon W & $3,601.000$ \\
Z & -2.204 \\
Asymp. Sig. (2-tailed) & 0.027 \\
\hline
\end{tabular}

Source: Processed Data, 2019

The adjusted $\mathrm{R}$ Square score is 0.426 , it means that the model shows the independent variable (corporate value) score $42.6 \%$, while the rest percentage is explained by other variables outside this study. The Odd Even Commissioner has an unstandardized coefficient score 1.082 with a $p$-value or significance score 0.036 . That score proves that the commissioner odd even influences the corporate's value. Indeed, the results of this study are in line with previous researchers namely Gao \& Huang (2018) and He \& Luo (2018). When the board of commissioners is formed with an odd number, the decision-making process will be easier and more efficient because there is no possibility of voting tie. It helps the board of commissioners to have the same perspective. This is different, if the board of commissioners is formed with an even number because it allows for a voting tie in the decision-making process so that it might cause different perspective in the board of commissioners.

Table 4. and Table 5. present the different Mann Whitney test results in determining whether there is a difference in the corporate value in companies which using the odd board commissioner or even board commissioner.

Indeed, the results show that there are significant differences of corporate value between companies that use the odd board commissioner and the even board commissioner. Furthermore, it can be seen that companies that use commissioner odd boards have a higher average company value, compared to companies that use commissioner even boards. These results are in line with multiple linear regression testing and it supports the research hypothesis. Gao \& Huang (2018) stated that there is two factors that play a role in determining the direction of voting, namely performance preference and conformity preference. Performance preference motivates the director to vote independently based on his own judgment and available information.

Conformity preferences encourage directors to choose decisions that are preferred by the majority vote. When faced with the event board of commissioners, there is a possibility of dissenting that is equally strong, so that the directors of the company tend to move according to performance preferences. On the other hand, when faced with an odd board of commissioners, directors will be confronted with a board of commissioners who tend to have the same perspective or the majority and minority perspective so that company directors tend to act in accordance with conformity preferences.

Table 5. Descriptive Results in the Mann-Whitney U Test

\begin{tabular}{|c|c|c|c|}
\hline Odd Even commissioner & $\mathrm{N}$ & Mean Rank & Sum of Ranks \\
\hline Even & 63 & 57.160 & 3601 \\
\hline Odd & 65 & 71.620 & 4655 \\
\hline Total & 128 & & \\
\hline
\end{tabular}

Source: Processed Data, 2019 
Islamudin, Wuriantara \& Bernawati

The Odd-Even Effect in The Boards of Commissioners and Corporate Values

Table 6. Multiple Linear Regression Testing on a small Board Size Commissioner

\begin{tabular}{lrrrrr}
\hline & \multicolumn{2}{l}{ Unstandardized } & \multicolumn{2}{c}{$\begin{array}{l}\text { Standardized } \\
\text { Coefficients }\end{array}$} & \multicolumn{2}{c}{ Coefficients } & \multirow{2}{*}{ t } & Sig. \\
\cline { 2 - 4 } & \multicolumn{1}{c}{$\mathrm{B}$} & \multicolumn{1}{c}{ Std. Error } & \multicolumn{1}{c}{ Beta } & & \\
\hline (Constant) & 60.940 & 11.870 & & 5.134 & 0.000 \\
Odd Even Commissioner & 2.378 & 0.907 & 0.280 & 2.621 & 0.011 \\
Size & -2.346 & 0.391 & -0.555 & -5.994 & 0.000 \\
Leverage & 4.952 & 2.047 & 0.228 & 2.419 & 0.018 \\
Independent Commissioner & 16.78 & 2.755 & 0.516 & 6.091 & 0.000 \\
Female Commissioner & 1.416 & 3.096 & 0.039 & 0.457 & 0.649 \\
Board Size & 0.896 & 0.434 & 0.227 & 2.063 & 0.043 \\
\hline Adjusted R Square & & & & & 0.480 \\
F Statistic & & & & & 13.135 \\
F Significance & & & & & 0.000 \\
\hline
\end{tabular}

Source : Processed Data, 2019

That score indicates that the odd even effect on the board of commissioners will be stronger in companies that have a small board of commissioners because the tendency for voting tie will also be higher compared to the large size board of commissioners. However, as the increasing number of commissioners, the possibility of voting ties and different perspective that are equally strong is also getting smaller. Therefore, to strengthen the results of the study, multiple linear regression testing was carried out on the structure of the small size board of commissioners (less than 7). The results are presented in Table 6. The results show that the significance level becomes stronger, which was previously at 0.036 become 0.011 .

\section{Conclusion}

This article extends the literacy about the characteristics of the board by adding a new perspective namely, odd-even effect in the structure of the board of commissioners. The odd or even proportions on the board of commissioners affects the corporate value. The results of this study also provide an overview of the agency theory that there is a conflict between the principal and the agent, through the results of this study it is possible that there is conflict within the majority agent and the minority agent. So, provide boards of commissioners with an odd number, is reduce the possibility of conflict in internal boards of commissioners. Boards of commissioners with an odd number have more efficient voting process and decision-making if it is compared to board of commissioners with an even number. Those efficiencies can affect the corporate value.

This article has limitations in the form of a relatively small research sample. This article uses limited research samples namely the companies that listed in the LQ 45 index. It is recommended that future research broader company samples, such as manufacturing companies. It is also recommended being able to explore the effectiveness of odd and even numbered board performance perspective.

\section{References}

Cadbury, A. (1992). Report of the committee on the financial aspects of corporate
governance (Vol. 1). Gee.
Campbell, K., \& Vera, A. M. (2010). Female board appointments and firm valuation:

Jurnal IImiah Akuntansi dan Bisnis, 2020 | 314 


\section{Islamudin, Wuriantara \& Bernawati \\ The Odd-Even Effect in The Boards of Commissioners and Corporate Values}

Short and long-term effects. Journal of Management \& Governance, 14(1), 37-59. Chung, K. H., \& Pruitt, S. W. (1994). A simple approximation of Tobin's q. Financial Management, 23(2), 70-74.

Damayanthi, I. G. A. E. (2019). Fenomena Faktor yang Mempengaruhi Nilai Perusahaan. Jurnal Ilmiah Akuntansi Dan Bisnis, 14(2), 208-218. https://doi.org/10.24843/JIAB.2019.v14.i02.p06

Darmadi, S. (2013). Do women in top management affect firm performance? Evidence from Indonesia. Corporate Governance: The International Journal of Business in Society. https://doi.org/10.2139/ssrn.1728572

Deng, X., Gao, H., \& Liu, W.-L. (2012). Voting Efficiency and the Even-Odd Effects of Corporate Board: Theory and Evidence. https://doi.org/10.2139/ssrn.2112880

Eisenhardt, K. M. (1989). Building theories from case study research. Academy of Management Review, 14(4), 532-550.

Gao, H., \& Huang, J. (2018). The even--odd nature of audit committees and corporate earnings quality. Journal of Accounting, Auditing \& Finance, 33(1), 98-122.

Hamdani, M. (2016). Good Corporate Governance (Gcg) Dalam Perspektif Agency Theory.

Harmono, D., \& Si, M. (2009). Manajemen Keuangan Berbasis Balance Scorecard. Pendekatan Teori, Kasus dan Riset Bisnis. Jakarta: Bumi Aksara.

He, W., \& Luo, J. (2018). Agency problems in firms with an even number of directors: Evidence from China. Journal of Banking \& Finance, 93, 139-150.

Hemastuti, C. P., \& Hermanto, S. B. (2014). Pengaruh profitabilitas, kebijakan dividen, kebijakan hutang, keputusan investasi dan kepemilikan insider terhadap nilai perusahaan. Jurnal Ilmu \& Riset Akuntansi, 3(4), 1-15.

Jensen, M. C., \& Meckling, W. H. (1976). Theory of the firm: Managerial behavior, agency costs and ownership structure. Journal of Financial Economics. https://doi.org/10.1016/0304-405X(76)90026-X

Masulis, R. W., Wang, C., \& Xie, F. (2012). Globalizing the boardroom-The effects of foreign directors on corporate governance and firm performance. Journal of Accounting and Economics, 53(3), 527-554.

Muryati, N. N. T. S., \& Suardikha, I. M. S. (2014). Pengaruh Corporate Governance Pada Nilai Perusahaan. E-Jurnal Akuntansi, 9(2), 425-429.

https://ojs.unud.ac.id/index.php/Akuntansi/article/view/9160

Oxelheim, L., \& Rand $\varnothing y$, T. (2003). The impact of foreign board membership on firm value. Journal of Banking \& Finance, 27(12), 2369-2392.

Prabowo, M., \& Simpson, J. (2011). Independent directors and firm performance in family controlled firms: evidence from Indonesia. Asian-Pacific Economic Literature, 25(1), 121-132.

Rasyidah, R. (2013). Perbandingan Corporate Governance dengan SistemOne-Tier Board di Inggris dan AS Terkait EfektififasPencegahan Terjadinya Fraud dalam Korporasi. Global \& Policy, 1(1), 11-18.

Schellenger, M. H., Wood, D. D., \& Tashakori, A. (1989). Board of Director Composition, Shareholder Wealth, and Dividend Policy. Journal of Management. https://doi.org/10.1177/014920638901500308

Sudiyatno, B., \& Puspitasari, E. (2010). Tobin's q dan altman z-score sebagai indikator pengukuran kinerja perusahaan. Kajian Akuntansi, 2(1).

Tambunan, M. C. S., Saifi, M., \& Hidayat, R. R. (2017). Pengaruh Good Corporate 
Islamudin, Wuriantara \& Bernawati

The Odd-Even Effect in The Boards of Commissioners and Corporate Values

Governance Terhadap Nilai Perusahaan (Studi pada Perusahaan Sub Sektor Food and Beverages yang Terdaftar di BEI Tahun 2012-2015). Jurnal Administrasi Bisnis, 53(1), 49-57.

Tricker, R. I. B., \& Tricker, R. I. (2015). Corporate governance: Principles, policies, and practices. Oxford University Press, USA.

Ullah, I., Fang, H., \& Jebran, K. (2019). Do gender diversity and CEO gender enhance firm's value? Evidence from an emerging economy. Corporate Governance: The International Journal of Business in Society, 20(1), 44-66.

https://doi.org/10.1108/CG-03-2019-0085 